\title{
Effect of Transglutaminase Addition on the Physicochemical Properties of Sodium Caseinate and Whey Proteins
}

\author{
Ji-Eun Jeong and Youn-Ho Hong* \\ Department of Food and Nutrition, College of Human Ecology. Human Ecology Research Institute, \\ Chonnam National University, Gwangju 500-757, Korea
}

\begin{abstract}
In this study, several factors were analyzed in an effort to determine the effects of transglutaminase (TGase) treatment on sodium caseinate $(\mathrm{NaCN}), \alpha$-lactalbumin $(\alpha$-La), and $\beta$-lactoglobulin $(\beta$ - $\mathrm{Lg})$ polymerization reactions. The results of SDSPAGE showed that $\mathrm{NaCN}$ was slightly hydrolyzed to molecular weights of $50-400 \mathrm{kDa}$ according to activation time. $\alpha$-La formed high-molecular polymers of 30-300 kDa, whereas $\beta$ - Lg remained almost completely unhydrolyzed. Melting temperatures of $\mathrm{NaCN}, \alpha$-La with and without TGase were all in the range of $100 \pm 10^{\circ} \mathrm{C}$ under the endothermic curve, and the melting temperature of $\beta-\mathrm{Lg}$ with TGase was lower than that with TGase. When the proteins were incubated for $3 \mathrm{~h}$ with TGase, the micrographic structures showed a small quantity of sediment and broad layers. The final $\alpha$-La residues remained at a level of $21.38 \%$, and the TGase-treated $\alpha$-La was confirmed to have undergone a profound loss of mass, to $18.25 \%$. The DPPH-radical scavenging activity of $\mathrm{NaCN}$ and $\beta$ - $\mathrm{Lg}$ with TGase treatment was higher than that observed in the untreated sample, while those of $\alpha$-La increased with concentration.
\end{abstract}

Key words : milk proteins, transglutaminase, polymerization, field-emission scanning electron microscopy, 1,1-diphenyl2-picryhydrazy-radical scavenging activity

\section{Introduction}

Food industries worldwide are currently attempting to develop new ingredients or dairy products with beneficial physical and functional characteristics. Several of the physico-chemical properties of milk proteins are fundamentally modified by the action of TGase, which may have applications in the manufacture of functional proteins for use as novel food ingredients (O'Sullivan et al., 2002). Transglutaminase (TGase, protein-glutamine $\gamma$-glutamyl transferase, EC 2.3.2.13) is an enzyme naturally present in most animal tissues and body fluids; it performs a crucial role in blood clot formation. With the recent discovery that this enzyme can be produced from a microbial source (Ando et al., 1989), its applications in the food industry are currently being increasingly investigated (Moon and Hong, 2003; Hwang et al., 2008; Lee and Chin, 2009).

Transglutaminase catalyzes an acyl transfer reaction

*Corresponding author : Youn-Ho Hong, Department of Food and Nutrition, Chonnam National University, Gwangju 500757, Korea. Tel: 82-62-530-1333; Fax: 82-62-530-1339, E-mail: yhhong@chonnam.ac.kr between $\gamma$-carboxyamide groups of peptide-bond glutamine residues (acyl donor) and the primary amino groups in a variety of amine compounds (acyl acceptor), including peptide-bond $\varepsilon$-amino groups of lysine residues. As a consequence of the crosslinking of peptide-bond glutamine and lysine residues, $\varepsilon$ - $(\gamma$-glutamyl)lysine isopeptide bonds and high-molecular weight polymers are formed. In the absence of amine substrates, TGase is capable of catalyzing the deamidation of glutamine residues (Motoki et al., 1986).

Numerous studies have been conducted regarding the effect of TGase on caseins (Ikura et al., 1980; Traore and Meunier, 1991; Sakamoto et al., 1994) and whey proteins (Ikura et al., 1980; Mahmound and Savello, 1992; Faergemand et al., 1997). Caseins and soya proteins, in which methionine and lysine (respectively) are limiting factors, may be enhanced by such a TGase reaction (Nonaka et al., 1996). TGase treatment applied to sodium caseinate $(\mathrm{NaCN})$ and whey protein isolate (WPI) improves solubility at $\mathrm{pH}$ values of 2 and 4 ; this effect has been attributed to the cross-linking of the individual caseins and whey proteins. The heat stability of $\mathrm{NaCN}$ remained nearly unchanged after TGase treatment. After crosslinking by TGase, whey protein evidenced enhanced 
heat stability as compared to the native protein at temperatures in excess of $70^{\circ} \mathrm{C}$. Additionally, in the SDS-PAGE results, the main bands of the sample evidenced high mobility and formed bands of molecular weights below $15 \mathrm{kDa}$ after hydrolysis with pepsin followed by TGasetreatment within $10 \mathrm{~min}$ of reaction time (Jeong and Hong, 2005; Jeong and Hong, 2006). The cross-linking was conducted using a TGase preparation containing glutathione in order to enhance the reactivity of TGase in unheated or pasteurized milk, allowing for the economic application of the enzyme in the manufacture of cheese (Bonisch et al., 2008). With regard to the range of TGase concentrations used for the assessment of the physical, chemical, and sensory properties of non-fat yogurt, a TGase level of $0.3 \mathrm{gL}^{-1}$ was considered optimal (Oze et al., 2007). Although the above reports provide us with a good understanding of the technological potential of the TGase reaction in dairy products, information regarding the relative susceptibility of individual milk proteins is currently lacking. Additionally, most of the studies have used indirect means of measuring the crosslinking reactions, and thus no distinction has yet been made between the crosslinking and other TGase-catalyzed reactions.

Understanding the reaction of TGase with caseins and whey proteins is critical to the optimization of the application of TGase in dairy products. In the current study, polymerization reactions, hydrolysis, thermal properties, and FE-SEM microphotographs, as well as [1,1-diphenyl2-picryhydrazy] (DPPH)-radical scavenging activity were employed to characterize the effects of the addition of TGase on the physicochemical properties of $\mathrm{NaCN}, \alpha-$ lactalbumin $(\alpha-\mathrm{La})$ and $\beta$-lactoglobulin $(\beta-\mathrm{Lg})$. By focusing the study on the entirety of the functional additives, novel insights can be acquired into the interaction between TGase cross-linking and $\mathrm{NaCN}, \alpha-\mathrm{La}$, and $\beta$-Lg.

\section{Materials and Methods}

\section{Raw materials}

$\mathrm{NaCN}$ (protein content 94.1\%, fat content max. 1.4\%) was obtained from Lactoport Deutschland $\mathrm{GmbH}$ (Kaltenkirchen, Germany). $\alpha$-La and $\beta$ - $L g$ were acquired from DAVISCO (Minnesota, USA). Samples of NaCN, $\alpha$-La, and $\beta$ - $\mathrm{Lg}$ were placed in a cold room $\left(-20 \pm 1^{\circ} \mathrm{C}\right)$.

A $\mathrm{Ca}^{2+}$-independent MTGase from Streptoverticillium mobaraense was utilized. The enzyme was kindly provided by Ajinomoto Foods (Tokyo, Japan). The microbial TGase preparation Activa ${ }^{\circledR}$-WM (E.C. 2.3.2.13) has been used previously for the modification of milk proteins.
According to the product specifications, this enzyme preparation is composed of TGase (1\%), lactose, and maltodextrin, with a specific enzyme activity of 100 units (U) per g powder. DPPH, dimethyl sulfoxide (DMSO), ethylenediamine-tetraacetic acid (EDTA), and $N$-ethylmaleimide (NEM) were purchased from Sigma Chemicals (St. Louis, MO, USA). Standard molecular markers were obtained from BioRad Laboratories (Richmond, CA, USA). All other reagents were of analytical grade, unless otherwise noted.

\section{Sample preparation}

Different milk proteins $(5 \%, \mathrm{w} / \mathrm{w})$ in $0.05 \mathrm{M}$ Tris- $\mathrm{HCl}$ buffer ( $\mathrm{pH} 7.0)$ were carefully added to TGase $(1 \%, \mathrm{v} / \mathrm{w})$ and after $3 \mathrm{~h}$ of incubation at $40^{\circ} \mathrm{C}$, and the enzyme was inactivated by $5 \mathrm{~min}$ of heat treatment at $80^{\circ} \mathrm{C}$ or NEM. Prior to the addition of the enzyme, the $\alpha-\mathrm{La}$ and $\beta-\mathrm{Lg}$ were heated in a temperature range around $37^{\circ} \mathrm{C}$ for $1 \mathrm{~h}$ with $5 \mathrm{mM}$ EDTA, according to the methods developed by Sharma et al. (2002). All samples were rapidly cooled to room temperature, lyophilized, and subsequently analyzed.

\section{Enzymatic hydrolysis in vitro}

The hydrolysis experiments of samples with TGase treatment were adapted from the work of Spellman et al. (2003). $5 \mathrm{~mL}$ of a $100 \mathrm{~mL}^{-1}$ aqueous solution of proteins was hydrated for $1 \mathrm{~h}$ at room temperature with gentle mixing. The protein solution was then $\mathrm{pH}$ adjusted to 7.0 with $2.0 \mathrm{~N} \mathrm{NaOH}$ followed by the addition of trypsin $(0.005 \%)$, and the mixture was incubated at $40^{\circ} \mathrm{C}$ for 0,5 , $10,30,60,120,180,240$ or $300 \mathrm{~min}$. The enzyme was subsequently inactivated by $5 \mathrm{~min}$ of heat treatment at $80^{\circ} \mathrm{C}$.

To assess their hydrolytic properties, the hydrolysates were analyzed via SDS-PAGE (sodium dodecylsulfate polyacrylamide gel electrophoresis) under the reducing conditions described by Laemmli (1970).

\section{Determination of the degeneration temperature and thermal properites}

The thermal denaturation of $\mathrm{NaCN}, \alpha-\mathrm{La}$, and $\beta-\mathrm{Lg}$ were monitored using a differential scanning calorimeter (DSC) model 2929 (TA Instrument, USA) with a scan rate of $3^{\circ} \mathrm{C} \mathrm{min}{ }^{-1}$. DSC was utilized to assess the energy of heat degeneration and kinetics figures at various protein concentrations, $\mathrm{pH}$ values, and ion compositions. After the dissolution of each sample into $0.2 \mathrm{M}$ phosphoric acid buffer solution ( $\mathrm{pH}$ 6.8), each sample was injected into a hermetic pan and sealed with a sample encapsulating press, after which the DSC thermograms 
were obtained via heat analysis curves with heating at $3^{\circ} \mathrm{C} / \mathrm{min}$ in a range of $20-180^{\circ} \mathrm{C}$. The mass of each sample was evaluated using a thermogravimetric analyzer (TGA-50) system (Shimadzu, Japan). The TGA system was used to measure the mass change of the sample as a function of time or temperature; using the measurement results, the pyrolysis curve of the sample which had already been polymerized could be measured. By measuring the pyrolysis curve, the polymerization and resolution could be compared. When the sample was resolved, the heated velocity was $10^{\circ} \mathrm{C} / \mathrm{min}$, and the range of temperature was $50-800^{\circ} \mathrm{C}$, under a current of nitrogen gas. The control group was used under identical circumstances, measuring only the phosphoric acid buffer solution.

\section{Scanning electron microscopy}

Acetone was added to the non-conduction sample to assess the histological polymerization of $\mathrm{NaCN}, \alpha-\mathrm{La}$, and $\beta$-Lg in TGase-treated samples using field-emission scanning electron microscopy (FE-SEM). A carbon covering was applied three times, and became conductive. The image was then observed using an FE-SEM (S-4700, Hitachi, Japan) in fixed state at a magnification of 600 , a phototime of $85 \mathrm{sec}$, and an acceleration voltage of 15 or $20 \mathrm{kV}$.

\section{Measurement of antioxidative activity}

The antioxidative activity of the hydrolyzed samples was evaluated by the method of Blois (1958). The rate was spectrophotometrically measured (U-2800A, Hitachi, Japan) via the addition of $4 \times 10^{-4} \mathrm{M}$ DPPH into each of the hydrolyzed solutions, all of which were subsequently dissolved into methanol or DMSO at constant concentrations for $30 \mathrm{sec}$ and assessed for extinction rate at $517 \mathrm{~nm}$. The control group was treated with methanol or DMSO instead of samples, and measured in the same fashion. The sample group evidenced reduced electron-donation ability, and the control group was used for data measurement via the addition of each sample. The amount of sample required to reduce the extinction rate by $50 \%$ was determined and expressed in terms of $\mathrm{EC}_{50}(\mathrm{mg} / \mathrm{mL})$, and the measurements were based on the electron donating ability (EDA) of each sample. An experiment using vitamin $\mathrm{C}$ as a positive control group was conducted in the same fashion, and the reduction ability of the TG-added and non-TG-added samples was compared. The electron donation ability of the samples were measured by the following equation:

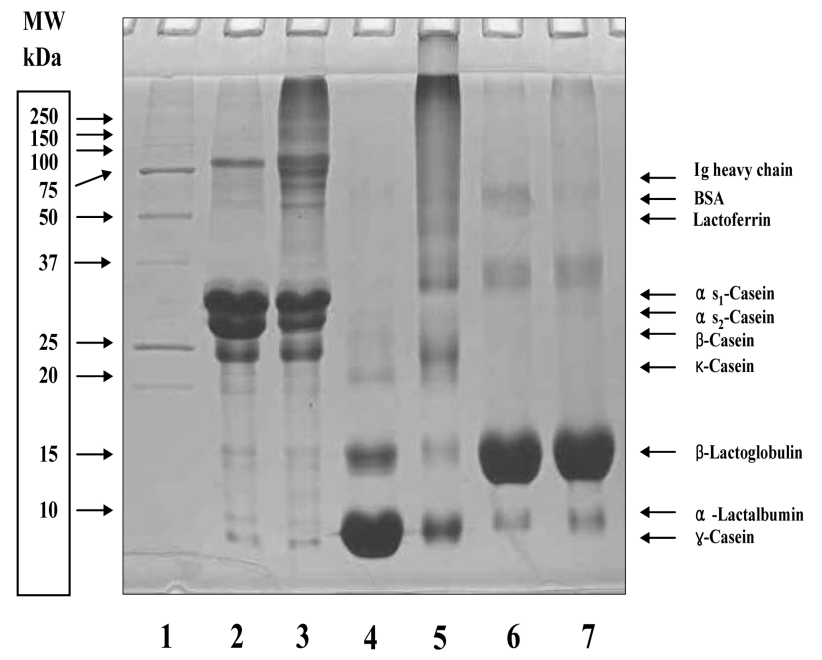

Fig. 1. SDS-PAGE pattern of $\mathrm{NaCN}, \alpha-\mathrm{La}$ and $\beta$-Lg with and without TGase for $3 \mathbf{h}$ of incubation. Lane 1: Molecular weight standard, lane 2: $\mathrm{NaCN}$, lane $3: \mathrm{NaCN}$ with TGase, lane 4: $\alpha$-La, lane 5: $\alpha$-La with TGase, lane 6: $\beta$ $\mathrm{Lg}$, lane 7: $\beta$-Lg with TGase.

$\operatorname{EDA}(\%)=(1-\mathrm{A} / \mathrm{B}) \times 100$

Where $A=$ Absorption of sample at $525 \mathrm{~nm}$

$\mathrm{B}=$ Absorption of control at $525 \mathrm{~nm}$

\section{Results and Discussion}

\section{Polymerization of $\mathrm{NaCN}, \alpha-\mathrm{La}$ and $\beta-\mathrm{Lg}$}

After the reaction with TGase at a rate of 1:100 (Enzyme: Substates), the results from the observation of the polymerization phase and protein fraction changes are shown in Fig. 1.

In the case of $\mathrm{NaCN}$ fractions, $\alpha s_{1^{-}}, \alpha s_{2,-}, \beta$-, and $\kappa-$ casein levels were all reduced after the polymerization reaction, the range of polymers produced by TGase was between $50-300 \mathrm{kDa}$, and generated the greatest quantity of milk protein. Sharma et al. (2002) previously reported that the $\alpha_{\mathrm{s} 1^{-}}$and $\beta$-caseins, in particular, appear to be readily cross-linkable, owing to their flexible, randomcoil structures and their lack of any disulphide bonds. In SDS-PAGE analyses, more pronounced protein crosslinking was noted under neutral than acidic conditions. It was assumed that, owing to the activity of TGase, electrostatic repulsion was partially negated on the surfaces of the sodium caseinate particles, thereby allowing, for example, hydrophobic interactions between the particles and gel formation (Partanen et al., 2008).

Our analysis with $\alpha$-La confirmed that the original protein fraction was greatly reduced and resulted in a significant amount of polymer polymerization, and most importantly, 

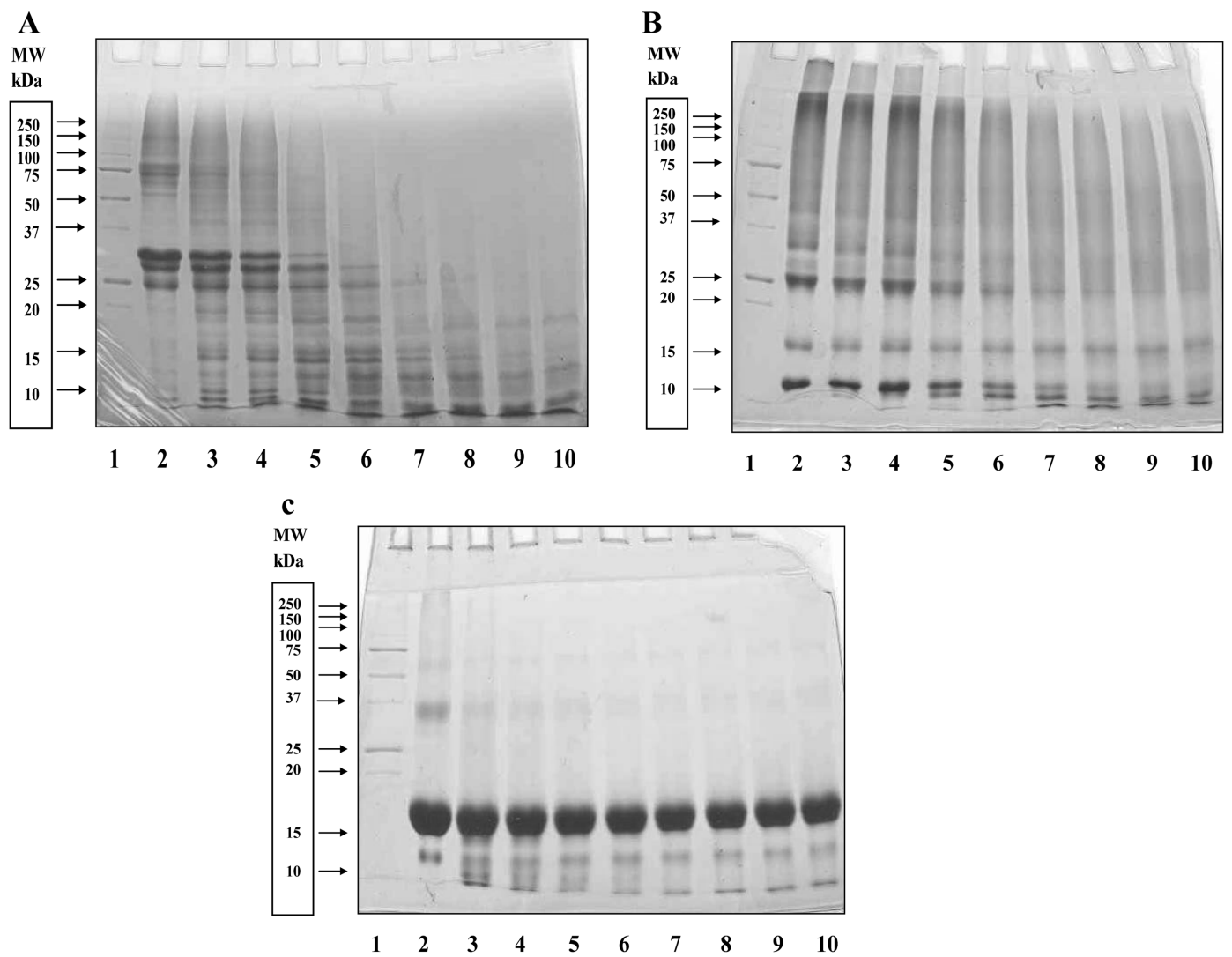

Fig. 2. SDS-PAGE pattern of peptides produced by trypsin hydrolysis of $\mathrm{NaCN}(\mathrm{A}), \alpha-\mathrm{La}(\mathrm{B})$, and $\beta$-Lg (C) with TGase. Conditions in terms of reaction time (lane 1: Molecular weight standard, lane 2: NaCN with TGase, lane 3: $5 \mathrm{~min}$, lane 4: $10 \mathrm{~min}$, lane 5: $30 \mathrm{~min}$, lane 6: $60 \mathrm{~min}$, lane 7: $120 \mathrm{~min}$, lane 8: $180 \mathrm{~min}$, lane 9: $240 \mathrm{~min}$, lane 10: $300 \mathrm{~min}$ ).

confirmed new fractions at approximately $25 \mathrm{kDa}$ and $30 \mathrm{kDa}$. Transformation by TGase to the apo form of $\alpha-\mathrm{La}$ in the molten state was studied under each different circumstance (Gu et al., 2001; Lee et al., 2002; Nieuwenhuisen et al., 2003).

$\beta$-Lg yielded a relatively small quantity of polymer as compared to other protein polymers despite three hours' reaction with TGase, in a range between $75 \mathrm{kDa}$ and $250 \mathrm{kDa}$ (Fig. 1). The degree of milk protein crosslinking generated by TGase increased in the following order: $\mathrm{NaCN}>$ $\alpha-\mathrm{La}>\beta$-Lg. $\beta$-Lg was unable to cross-link without any reduction in its disulphide bonds (Sharma et al., 2002).

\section{Effect to hydrolysis of cross-linked $\mathrm{NaCN}, \alpha-\mathrm{La}$ and $\beta-\mathrm{Lg}$}

Fig. 2 shows the hydrolysis behavior of the trypsin treatment applied to the polymerized samples by TGase. As reaction time increased by 5,10 , and $30 \mathrm{~min}$, polymerization in the range of $50-300 \mathrm{kDa}$ was resolved by trypsin, but it remained unclear after $60 \mathrm{~min}$. The lowpolymerized fraction increased in the range of $10-15 \mathrm{kDa}$. Additionally, $\alpha \mathrm{s}_{1}$-casein was eliminated by $60 \mathrm{~min}$ of elapsed time from the beginning of the reaction. After that time, peptides above $15 \mathrm{kDa}$ were resolved and lower-weight molecules were also resolved (Fig. 2A).
$\alpha$-La was formed as a high-weight molecule by TGase, and appeared on the wells and stacking gel, additionally, a wide variety of polymers in the range of $30-300 \mathrm{kDa}$ were formed. $\alpha$-La was also hydrolyzed and reduced after two hours. In addition, the new $25 \mathrm{kDa}$ protein band made by TGase was slowly hydrolyzed, and was completely eliminated after one hour, as a single band formed. $\alpha$-La was hydrolyzed into divided peptides after $30 \mathrm{~min}$, and gradually resolved (Fig. 2B).

Owing to their compact globular structure, whey proteins tend to cross-link less efficiently (Aboumahmoud and Savello, 1990). In a recent study regarding the crosslinking of whey proteins from an industrial whey protein isolate (WPI) and a $\beta$-Lg preparation, Faergemand et al., (1997) reported that $\beta$-Lg was unable to cross-link without any reduction in its disulphide bonds, whereas $\alpha$-La could be cross-linked without reduction.

$\beta-\mathrm{Lg}$ does not interact due to its extraordinary protein structure, as has also been reported in the study of Adams et al., (1996); thus, scarcely any effects of TGase were noted in that case. As the hydrolysis reaction was initiated, some of the protein was hydrolyzed to peptides of less than $15 \mathrm{kDa}$ and resolved after $30-60 \mathrm{~min}$. Some quantity of $\beta-\mathrm{Lg}$ re- 

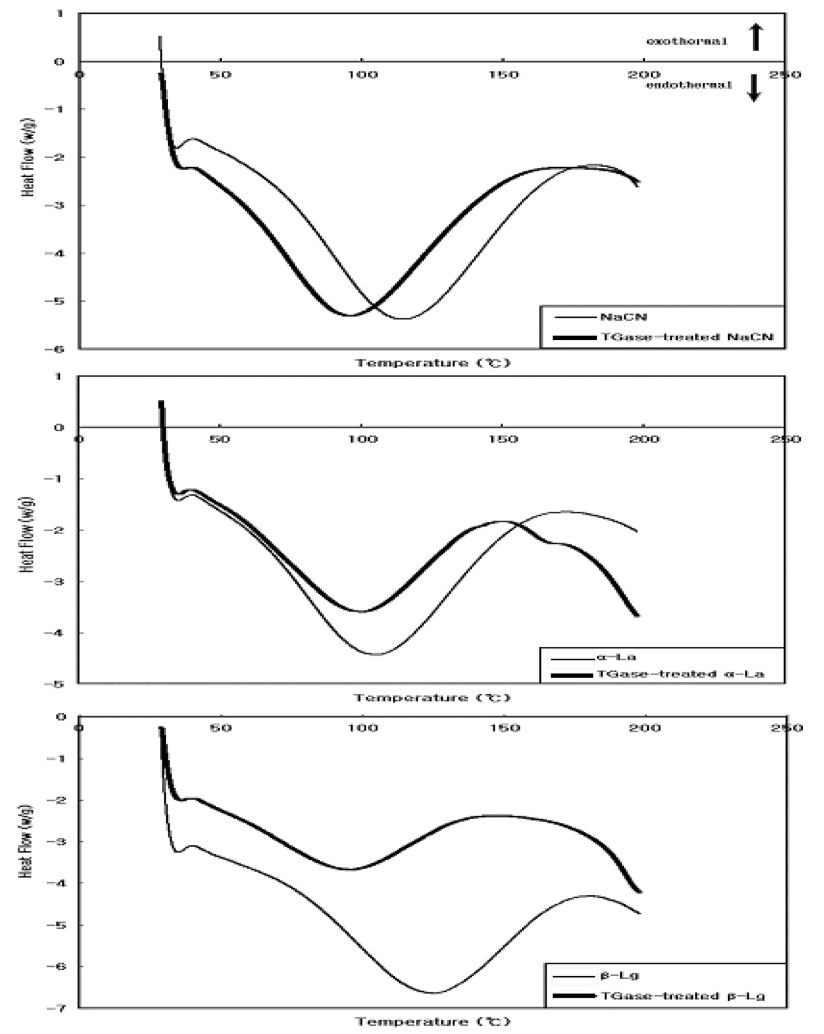

Fig. 3. DSC thermograms of $\mathrm{NaCN}, \alpha-\mathrm{La}$, and $\beta$-Lg with and without TGase heated from 25 to $100^{\circ} \mathrm{C}$. Heating rate was $3^{\circ} \mathrm{C} / \mathrm{min}$ under nitrogen gas. Solid lines designate spectra of native and bold lines designate the spectra of TGase treatment groups.

mained after five hours of the final reaction (Fig. 2C).

\section{Degeneration of protein and thermolysis properties}

DSC was conducted by heat analysis to evaluate changes in the polymerization states of $\mathrm{NaCN}, \alpha-\mathrm{La}$, and $\beta$ - $\mathrm{Lg}$ among the milk proteins. The results are provided in Fig. 3. As the experiment was initiated at $25^{\circ} \mathrm{C}$, the curves of all samples evidenced bending. In this region, heating circumstances changed dramatically from a constant temperature state of stand-by to a linear increase mode, and this phenomenon was attributed to an abundance of electronic current. $\mathrm{NaCN}$ in an unpolymerized state was degenerated at a temperature near $115^{\circ} \mathrm{C}$, and an endothermic peak was detected. In the case of $\mathrm{NaCN}$ in polymerization state, a maximum endothermic peak was measured at a temperature of near $90^{\circ} \mathrm{C}$, which is lower than that of the former, and the amount was similar. This observed discrepancy in peak temperature may be ascribable to solvent-evaporation, cross-linking, and polymerization. The $\alpha$-La was degenerated, and evidenced no relation with polymerization at temperatures below $100^{\circ} \mathrm{C}$. The degree of denaturation of $\alpha$-La without TGase was rela-
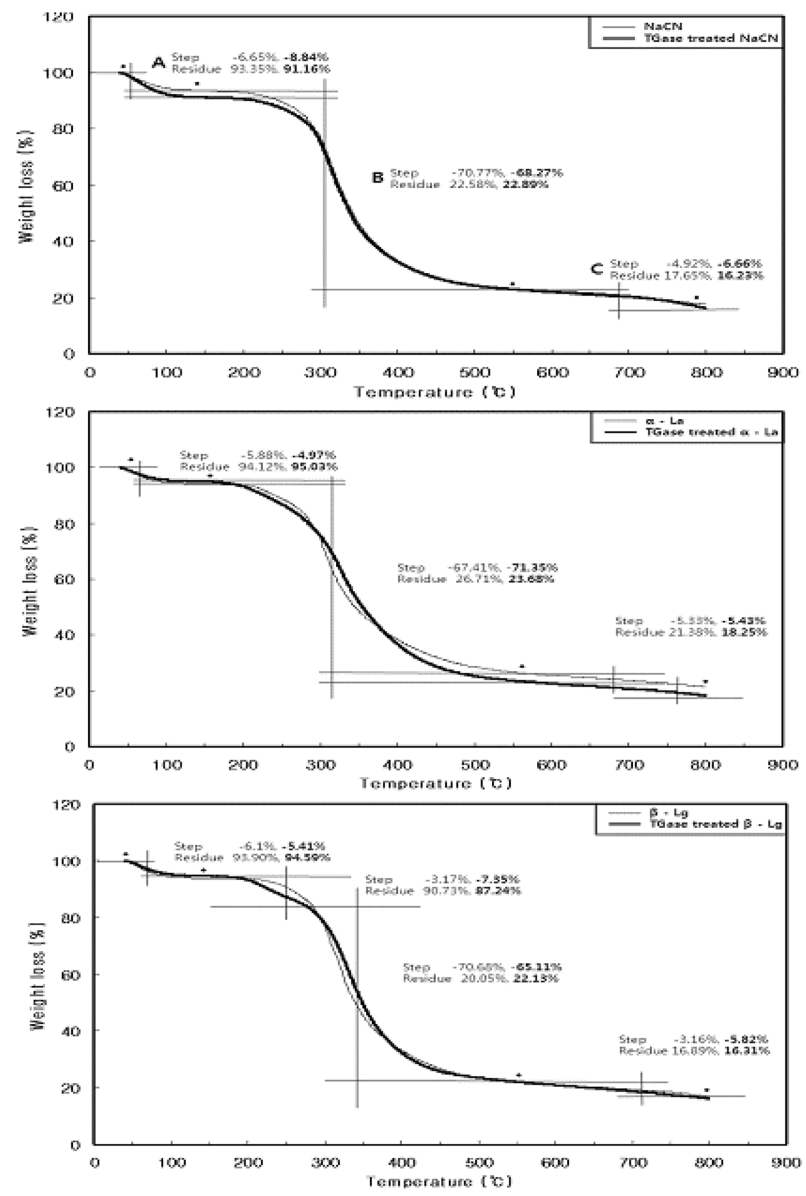

Fig. 4. TGA thermograms of $\mathrm{NaCN}, \alpha-\mathrm{La}$, and $\beta$-Lg with and without TGase heated from 50 to $800^{\circ} \mathrm{C}$. The heating rate was $10^{\circ} \mathrm{C} / \mathrm{min}$ under nitrogen gas. Solid lines designate the spectra of the native sample, and the Bold lines designate the spectra of TGase treatment. Marking with

indicates a continuous spot on samples' weight loss.

tively higher than in the other samples. The temperature at which $\beta$-Lg evidenced maximum heat absorption enthalpy was near $90^{\circ} \mathrm{C}$ from the original state; it was $120^{\circ} \mathrm{C}$ in polymerized form, and the degeneration energy absorption degree was lowered substantially after polymerization. Therefore, the degeneration temperature according to the first heat absorption curve (to $200^{\circ} \mathrm{C}$ ) was $100 \pm 10^{\circ} \mathrm{C}$ at all samples, and the degree of degeneration was similar to or lower than that associated with TGase treatment. In the case of $\beta$-Lg, the largest observed difference $\left(100 \pm 20^{\circ} \mathrm{C}\right)$ was shown to depend on with or without TGase. According to the report of Boye and Alli (2000), the endothermic reaction of $\alpha$-La and $\beta$ - $\mathrm{Lg}$ was denatured significantly at $\sim 62$ and $\sim 75^{\circ} \mathrm{C}$, respectively. When $100 \mathrm{mM}$ of $\mathrm{NaCl}$ was added to $3.0 \%$ whey protein isolate, we noted a degeneration of heat absorption at $\sim 87^{\circ} \mathrm{C}$. The unfolding of proteins affects heat absorption via the disruption of non-covalent or disulfide bonds, while it was degenerated by heat and 
absorbed heat (Fitzsimons et al., 2007). As compared with the reports of other researchers, the degeneration temperature of $\mathrm{NaCN}, \alpha-\mathrm{La}$, and $\beta-\mathrm{Lg}$ appeared relatively high. This difference was attributed to the particular materials used, including in separation, refining, the whole process, and the production method.

Fig. 4 provides the results of heat stability tests and pyrolysis temperature measurements by TGA in the polymerization state of $\mathrm{NaCN}, \alpha-\mathrm{La}$, and $\beta$-Lg. On the TGA curve, refers to the transition point at which the sample's mass loss was constant, and the difference between these two points was expressed in terms of mass loss (step) $\%$ and residue material $\%$. In the A section $\left(100-300^{\circ} \mathrm{C}\right)$, relatively low temperatures, water or residual solvents, and volatile materials like added oil were initially omitted. At this time, mass loss occurred from original milk protein in the range of $5.88-6.65 \%$, and $93.35-94.12 \%$ of it remained. NaCN's polymerized form (bold line) evidenced quite a large loss in mass, but mass loss in the polymerization of $\alpha$-La and $\beta$ - $\operatorname{Lg}$ was relatively small, at $0.69-0.91 \%$. After this, crystallized water was eliminated from the temperature at near $200^{\circ} \mathrm{C}$, the combustion and dissolution reaction was initiated from the $\mathrm{B}$ section $\left(300-550^{\circ} \mathrm{C}\right)$ to the $\mathrm{C}$ section $\left(550-800^{\circ} \mathrm{C}\right)$, and these reactions evidenced similar phase without any relation to whether or not $\mathrm{NaCN}$ was treated with TGase-nearly $22 \%$ of the sample remained. The $\alpha$-La sample polymerized by TGase at the early phase of division was reduced in a temperature range of $200-300^{\circ} \mathrm{C}$, and the mass of the non-TGase-treated group was reduced at temperatures above $300^{\circ} \mathrm{C}$. Additionally, the mass loss of $71.35 \%$ occurred at $550^{\circ} \mathrm{C}$, which is at the end of the $\mathrm{B}$ section, and thus the mass loss width of the enzyme-treated group and the nontreated group was $3.06 \% .21 .38 \%$ of the remaining $\alpha-\mathrm{La}$ material persisted until the final pyrolysis temperature was reached $\left(800^{\circ} \mathrm{C}\right)$. The TGase-treated group evidenced a mass loss of $18.25 \%$, which was a relatively larger amount. $\beta$-Lg had a total of 4 pyrolysis transition points, and these occurred in a range between $93.90-94.59 \%$; this was similar to that noted in the TGase-treated samples $\left(50-200^{\circ} \mathrm{C}\right)$. In the early A section, the mass loss of the early transition point (5.41-6.1\%) was attributed to the evaporation of internal $\beta$-Lg molecules. Afterward, mass loss in the TGase-treated group was noted at temperatures up to $300^{\circ} \mathrm{C}$, in accordance with the fact that mass loss at the high temperature of $550^{\circ} \mathrm{C}$ in the final B section was detected at $22.05-22.13 \%$. The loss rate of $\beta-\mathrm{Lg}$ from $50^{\circ} \mathrm{C}$ to $800^{\circ} \mathrm{C}$ was $83.11 \%$, whereas the TGase-treated $\beta$ $\mathrm{Lg}$ evidenced a rate of $16.31 \%$.

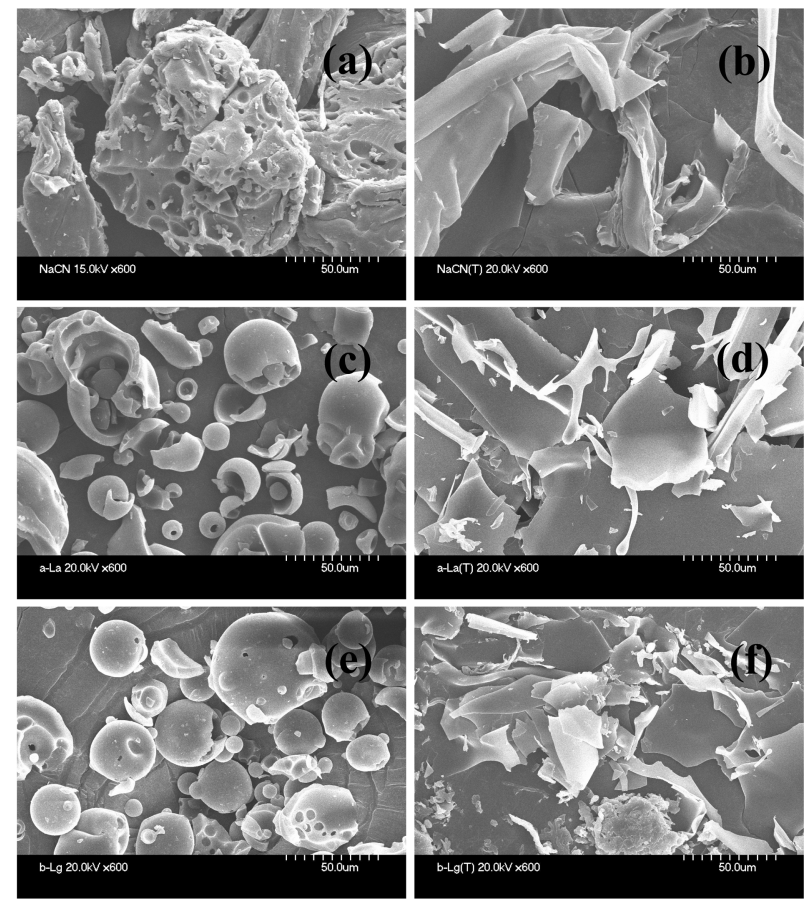

Fig. 5. FE-SEM of NaCN, $\alpha$-La and $\beta$-Lg powder without (a, c, e) and with (b, d, f) polymerization by TGase. The FE-SEM structure of freeze-dried $\mathrm{NaCN}, \alpha-\mathrm{La}$ and $\beta-\mathrm{Lg}$ to which TGase was added and incubated for $3 \mathrm{~h}$ at $37^{\circ} \mathrm{C}$. The scale bar represents $50 \mu \mathrm{m}$.

\section{Microstructural properties}

The SEM images of TGase-added and lyophilized milk proteins are provided in Fig. 5. The NaCN particles featured thick tissues and partial small stoma, and a generally unorganized form with rough surfaces (a). Additionally, TGase-treated $\mathrm{NaCN}$ exhibited no small stoma and appeared to have a face organized by enzyme (b). $\alpha$-La evidenced a circular or cracked particle shape, featuring a soft surface, and some of the particles exhibited small grooves (c). $\alpha$-La had no stoma, which were observed as fine, wide surfaces after polymerization with TGase. Not only soft-surfaced particles, but also long branch-shaped particles were noted (d). $\beta$-Lg featured typical circular and fixed particles and a somewhat rougher surface than was observed for $\alpha$-La, and was shown to facilitate the development of the fixed form of the particle (e). When the $\beta$ $\mathrm{Lg}$ is polymerized, it evidenced a form similar to that of $\alpha-\mathrm{La}$, which has a fine surface, but the length was shorter, and one large particle composed of several small particles was detected (f). Similarly, the matrix was readily formed via the formation of a covalent bond between small water-soluble proteins. GL cross-linked polymer material was observed to form a wide surface between proteins. 


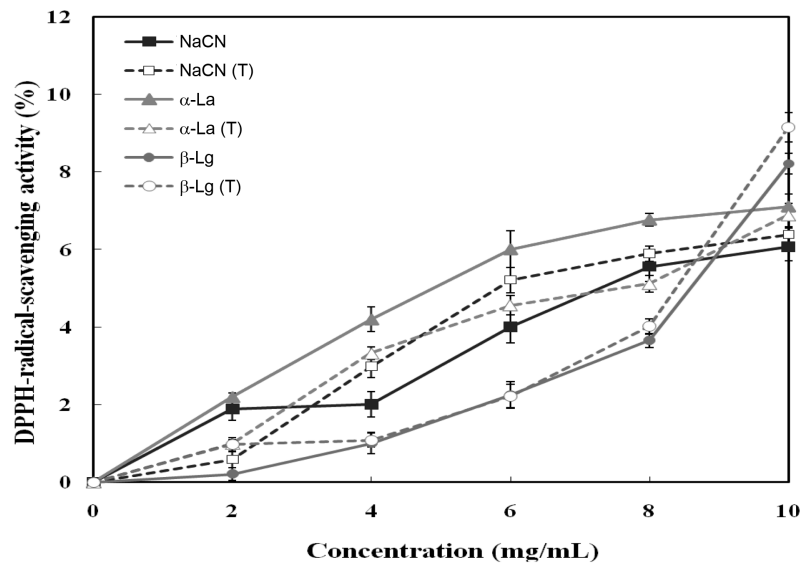

Fig. 6. Antioxidant activity of $\mathrm{NaCN}, \alpha-\mathrm{La}$ and $\beta$-Lg powder with and without TGase by DPPH radical scavenging method. ${ }^{1)} \mathrm{NaCN}(\boldsymbol{\square}), \alpha-\mathrm{La}(\boldsymbol{\Delta})$, and $\beta-\operatorname{Lg}(\boldsymbol{\bullet})$ were treated with $\mathrm{T}$ (TGase, $\square, \triangle, \bigcirc$ ), respectively. Mean values and standard deviations(error bars) of three replications are shown.

\section{DPPH free radical elimination ability}

The results regarding the polymerization of milk proteins by each concentration are shown in Fig. 6. Antioxidative activity increased with increasing concentrations of milk protein, and the activity was measured in the following order: $\beta-\mathrm{Lg}>\alpha-\mathrm{La}>\mathrm{NaCN}$. The sample's $\mathrm{EC}_{50}(\mathrm{mg} /$ $\mathrm{mL}$ ) was $>100 \mathrm{mg} / \mathrm{mL}$, but did not reach a level of 0.011 $\mathrm{mg} / \mathrm{mL}$, as compared to the data from the vitamin C positive control group. None of the milk protein groups treated with TGase nor the non-treated group evidenced particularly profound antioxidative activity. However, in the case of $\mathrm{NaCN}$ and $\beta$ - $\mathrm{Lg}$, the TGase-treated group evidenced higher antioxidative activity than the non-treated group. As the concentration of $\alpha$-La increases, antioxidative activity also increases; however, this increase was not particularly profound, and was similar to that of the TGasetreated group's antioxidative activity, at $10 \mathrm{mg} / \mathrm{mL}$.

Whey protein is rich in cysteine and methionine, both of which are elements of glutathione, and sulfur-containing amino acids result consistently in antioxidative ability and stabilize the DNA when the cell divides (Anderson, 1998).

\section{Conclusion}

In this study, we evaluated the physico-chemical properties inherent to the production of TGase-treated dairy ingredients, with added $\mathrm{NaCN}, \alpha-\mathrm{La}$, and $\beta$-Lg. The results of SDS-PAGE showed that $\mathrm{NaCN}$ and $\alpha$-La induced polymerization at above $37 \mathrm{kDa}$ via cross-linking, but $\beta$-Lg was unable to cross-link without reductions in its disulphide bonds. The denaturation temperature of the samples was quite high, at $90-100^{\circ} \mathrm{C}$. After TGase treatment, $\mathrm{NaCN}$ and $\beta$-Lg were denatured at lower temperatures and absorbed heat, $\beta$-Lg evidenced the lowest degree of denaturation, whereas the denaturation temperature of TGase-treated $\alpha$-La was similar to that of nonheated $\alpha$-La. The largest reduction of mass was observed in the pyrolysis phase, at approximately $200^{\circ} \mathrm{C}$, and $16-$ $17 \%$ of $\mathrm{NaCN}$ and $\beta-\mathrm{Lg}$ remained after heating to $800^{\circ} \mathrm{C}$. In the final reaction section, the results were similar to those observed with the TGase-treated samples. When treated with TGase, $\alpha$-La lost more mass. Under microscopy, the circular protein structures did not evidence stoma with wide, fine surfaces, after reaction with TGase. The antioxidative activity in the samples was not sufficient to eliminate free radicals, but the TGase-treated $\beta$ Lg group evidenced higher antioxidative activity than that of the non-treated group. Moreover, the antioxidative activity of $\alpha$-La increased in proportion to concentration, and evidenced similar activity to the group treated with $10 \mathrm{mg} / \mathrm{mL}$.

The results of this study demonstrate that $\mathrm{NaCN}, \alpha-\mathrm{La}$, and $\beta$-Lg polymers treated with TGase are significantly functional materials that exhibit physiological activities. Further studies, including in vivo experiments and clinical studies, will be required to evaluate the process by which dairy ingredients are digested and absorbed, as well as their utilization.

\section{Acknowledgements}

This study was financially supported by Special Research Program of Chonnam National University, 2009.

We thank Davisco Foods International for their generous donation of the $\alpha-\mathrm{La}$ and $\beta$-Lg, and Samik Dairy Co. for donating the $\mathrm{NaCN}$ used in this study.

\section{References}

1. Aboumahmoud, R. and Savello, P. (1990) Crosslinking of whey protein by transglutaminase. J. Dairy Sci. 73, 256-263.

2. Anderson, M. E. (1998) Glutathione: an overview of biosynthesis and modulation. Chemico-Biological Interactions. Archives Biochem. Biophys. 321, 6-12.

3. Ando, H., Adachi, M., Umeda, K., Matsuura, A., Nonaka, M., Uchio, R., Tanaka, H., and Motoki, M. (1989) Purification and characteristics of a novel transglutaminase derived from microorganisms. Agric. Biol. Chem. 53, 2613-2617.

4. Blois, M. S. (1958) Antioxidant determination by the use of a stable free radical. Nature 181, 1199-1200.

5. Bonisch, M. P., Heidebach, T. C., and Kulozik, U. (2008) Influ- 
ence of transglutaminase protein cross-linking on the rennet coagulation of casein. Food Hydrocolloids 22, 288-297.

6. Boye, J. I. and Alli, I. (2000) Thermal denaturation of mixtures of $\alpha$-lactalbumin and $\beta$-lactoglobulin: A differential scanning calorimetric study. Food Res. Int. 33, 673-682.

7. Faergemand, M., Otte, J., and Qvist, K. B. (1997) Enzymatic cross-linking of whey proteins by a $\mathrm{Ca}^{2+}$-independent microbial transglutaminase from Streptomyces lydicus. Food Hydrocolloids 11, 19-25.

8. Fitzsimons, S. M., Mulvihill, D. M., and Morris, E. R. (2007) Denaturation and aggregation processes in thermal gelation of whey proteins resolved by differential scanning calorimetry. Food Hydrocolloids 21, 638-644.

9. Gu, Y. S., Matsumura, Y., Yamaguchi, S., and Mori, T. (2001) Action of protein-glutaminase on $\alpha$-lactalbumin in the native and molten globule states. J. Agric. Food Chem. 49, 5999-6005.

10. Hwang, J. S., Lee, H. C., and Chin, G. B. (2008) Rheological properties of pork myofibrillar protein and sodium caseinate mixture as affected by transglutaminase with various incubation temperatures and times. Korean J. Food Sci. Animal Resour. 28 (2), 154-159.

11. Ikura, K., Kometani, T., Yoshikawa, M., Sasaki, R., and Chiba, H. (1980) Crosslinking of casein components by transglutaminase. Agric. Biol. Chem. 44, 1567-1573.

12. Jeong, J. E. and Hong, Y. H. (2005) Properties of Transglutaminase treated milk product powders. Kor. J. Food Sci. Technol. 37, 345-351.

13. Jeong, J. E. and Hong, Y. H. (2006) Electrophoretical properties of transglutaminase treated milk product powders. Kor. J. Food Sci. Technol. 38, 304-308.

14. Laemmli, U. K. (1970) Cleavage of structural proteins during the assembly of the head of bacteriophage T4. Nature 227, 680-685.

15. Lee, D. S., Matsumoto, S., Matsumura, Y., and Mori, T. (2002) Identification of the $\varepsilon-\gamma$ (glutamyl) lysine crosslinking site in $\alpha$-lactalbumin polymerized by mammalian and microbial transglutaminases. J. Agric. Food Chem. 50, 7412-7419.

16. Lee, H. C. and Chin, G. B. (2009) Effect of transglutaminase, acorn, and mungbean powder on quality characteristics of low-fat/salt pork model sausages. Korean J. Food Sci. Animal Resour. 29, 374-381.

17. Mahmound, R. and Savello, P. A. (1992) Mechanical proper- ties and water vapor transferability through whey protein films. J. Dairy Sci. 75, 942-946.

18. Moon, J. H. and Hong, Y. H. (2003) Electron microscopical property of transglutaminase added milk. Korean J. Food Sci. Animal Resour. 23, 350-355.

19. Nieuwenhuisen, W. F., Dekker, H. L., De, K. L., Groneveld, T., De, K. C. G., and De, J. G. A. (2003) Modification of glutamine and lysine residues in holo and apo $\alpha$-lactalbumin with microbial transglutaminase. J. Agric. Food Chem. 51, 7132-7139.

20. Nonaka, M., Matsumura, Y., and Motoki, M. (1996) Incorporation of lysine- and lysine dipeptides into $\alpha \mathrm{s}_{1}$-casein by $\mathrm{Ca}^{2+}$-independent Microbial transglutaminase. Biosci. Biotechnol. Biochem. 60, 131-133.

21. Nonaka, M., Toiguchi, S., Sakamoto, H., Kawajiri, H., Soeda, T., and Motoki, M. (1994) Changes caused by microbial transglutaminase on physical properties of thermally induced soy protein gels. Food Hydrocolloids 8, 1-8.

22. O'Sullivan, M. M., Kelly, A. L., and Fox, P. F. (2002) Influence of trans- glutaminase treatment on some physico-chemical properties of milk. J. Dairy Res. 69, 433-442.

23. Ozer, B., Kirmaci, H.A., Oztekin, S., Hayaloglu, A., and Atamer, M (2007) Incorporation of microfical transglutaminase into non-fat yogurt production. Int. Dairy J. 17, 199-207.

24. Partanen, R., Autio, K., Myllarinen, P., Lille, M., Buchert, J., and Forssell, P. (2008) Effect of transglutaminase on structure and syneresis of neutral and acidic sodium caseinate gels. Int. Dairy J. 18, 414-421.

25. Sakamoto, H., Kumizawa, Y., and Motoki, M. (1994) Strength of protein gels prepared with microbial transglutaminase as related to reaction conditions. J. Food Sci. 59, 866-871.

26. Sharma, R., Zakora, M., and Qvist, K. B. (2002) Susceptibility of an industrial $\alpha$-lactalbumin concentrate to cross-linking by microbial transglutaminase. Int. Dairy J. 12, 1005-1012.

27. Spellman, E., McEvoy, G., O'Cuinn, R., and FitzGerald, J. (2003) Proteinase and exopeptidase hydrolysis of whey protein: Comparison of the TNBS, OPA and $\mathrm{pH}$ stat methods for quantification of degree of hydrolysis. Int. Dairy J. 13, 447-453.

28. Traore, F. and Meunier, J. (1991) Cross-linking of caseins by human placental factor X IIIa. J. Agric. Food Chem. 39, 1892-1896.

(Received 2009.1.29/Revised 1st 2009.4.12, 2nd 2009.7.16, 3rd 2009.8.4/Accepted 2009.8.5) 